\title{
Smallholder Dairy Farm Management in Ethiopia: Status in Hawassa and Debrebrihan Cities
}

\section{Solomon Mekuria*}

Department of Veterinary Medicine, School of Veterinary Medicine, Hawassa University, Ethiopia

*Corresponding author: Solomon Mekuria, Department of Veterinary Medicine, School of Veterinary Medicine, Hawassa University, Ethiopia, Tel: +251462200050; Email: solmk2010@gmail.com

Received date: Jan 28, 2016; Accepted date: Feb 24, 2016; Published date: Feb 26, 2016

Copyright: @ 2016 Mekuria S. This is an open-access article distributed under the terms of the Creative Commons Attribution License, which permits unrestricted use, distribution, and reproduction in any medium, provided the original author and source are credited.

\begin{abstract}
Reproductive performance and milk bacteria study carried out using questionnaire survey and milk bacteriology from December, 2011 to March, 2013 in Hawassa and Debrebrihan cities. Four hundred forty nine household interviewed and 87 pooled milk samples research work result were used to draw inference about smallholder dairy farm management in the study area. It was observed that there was no plot for forage development in sampled household and there was poor feeding, housing and health management. Cross breed and local zebu were breed by artificial insemination $(72 \%)$ and natural mating $(28 \%)$ in Hawassa, whereas almost all cross breed animals were breed by natural mating (85\%) in Debrebrehan the remaining was artificial insemination. Health problems of calf mortality $(34 \%)$, infectious $(13 \%)$, retained placenta $(10 \%)$, dystocia $(5 \%)$, mastitis $(8 \%)$ and others were reported. Average milk yield in cross breeds were 6-10 liters and local zebu produce an average range of 2-4 liters. There was significant difference $(p<0.05)$ in calving interval, where local breed had $14.2 \pm 0.44$ months than others; age at first calving was $33.9 \pm 0.9$ than other breeds the difference was significant $(p<0.05)$. Number of service per conception using artificial insemination was within the range of 1.18 up to 1.72 in majority of the selected animals which was in the accepted ranges. Bacterial milk assessment indicated that different gram positive and negative bacteria observed, showing the level of bacterial contamination The study indicates that there was clear managerial problems in smallholder dairy farms, where feeding, housing, health and milk quality management were poor. Therefore, strong policy should be implemented in order to leverage the existing smallholder dairy farm status in the country in general.
\end{abstract}

Keywords: Small holders; Dairy farms; Health; Reproduction; Milk bacteria; Management; Ethiopia

\section{Introduction}

Epidemiological studies of dairy farm management in Ethiopia in particular, worldwide in general used to examine potential associations between an observed index of health or productivity or various characteristics of management and environment of the livestock. Currently Ethiopia restructured livestock subsector so as to maximize the reproduction and production of livestock, especially dairy farm in order to cope up with milk and meat demand as the result of urbanization and population growth [1]. Such kinds of studies help for those who are working with producers to address herd production problems.

Herd average milk production can be regarded as one important measure of the performance of a dairy herd. Often this performance is influenced by various factors, including genetics, nutrition, environment and management [2]. Large segment of livestock production sub-sector except few dairy farms, are managed under extensive traditional grazing system in Ethiopia [3]. All cattle production system in rural area, regardless of pastoral and sedentary farmers rear local breeds which are genetically low milk and meat producers; whereas few dairy farms in urban and peri urban area have kept cross breeds. To enhance dairy farm production the government and non-government organization have exerted their effort through training, provision of artificial insemination (AI) equipment and have established bull station in selected area. Inseminator and animal owners have been trained extensively in order to increase their understanding towards reproductive performance [1].

Hawassa and Debrebirhan cities are growing cities, where there is steady population growth, which becomes a driving force for the development of small dairy farms in the area to meet nutritional demand in the area.

However, despite the rapid population growth, the smallholder dairy sector is faced with several challenges. These include limited breeding stock, low productivity, poor management and inadequate extension service, health and other support services [4]. These challenges have negative impacts on milk productivity and reproduction [5,6]. It is important to determine the major factors associated with low fertility, herd growth and productivity. Herd growth may not be the target for most smallholder farmers as keeping more animals may not be practical and economically viable. However, successful reproduction is still important as the farmers benefit through continued milk production and sales of weaned calves [7]. This study analyzes the situation and cow fertility and outlines major challenges and possible solutions in the study area. In line with this idea research was conducted in Hawassa and Debrebirhan cities with the following objectives:

Measuring the reproductive performance of small holder dairy cows in both cities using certain parameters.

At Hawassa dairy farm collecting center major milk bacteria are observed. 


\section{Materials and Methods}

\section{Study area}

The study was conducted from December 2011 to March, 2013 in Hawassa and Debrebrehan cities. Hawassa is regional city of Southern Nation and Nationality People Regional state (SNNPRs) and located $275 \mathrm{Km}$ away from Addis Ababa in southern direction. The area lies between the altitudes of 1500-2000 meter above sea level and between 4.27 and $8.3^{\circ} \mathrm{N}-34.21$ and $39.1^{\circ} \mathrm{E}$. The annual mean rainfall is from $800-1000 \mathrm{~mm}$ and annual mean temperature is between $20.1-25^{\circ} \mathrm{C}$ [8]. Whereas, Debrebirhan city is located at the North Eastern direction at a distance of $137 \mathrm{~km}$ away from the capital city Addis Ababa. The altitude of the area ranges from 2638-2800 meter above sea level.

\section{Study methodology}

Smallholder dairy farms in Hawassa and Debrebirhan cities used as target population for this study. Animal owners interviewed and information collected about reproductive and productive parameters from each selected household.

Study conducted using two types of questionnaires: close ended questionnaire were used to assess reproductive performance parameters whereas open ended questionnaire were used to assess major constraints that remained a bottleneck in dairy developments in the dairy farm. Questionnaire was tested before the actual data collection. Parameters like calving interval, service per conception, use of AI, breed, age at first calving, milk yield per day and etc., were included during data collection. Information about constraints was open ended regardless of the number of animals present in the selected farm. Initially, 249 owners interviewed at Hawassa city, in second round 200 small holders were interviewed in Debre Birhan. In addition, bacteriological study was incorporated to appreciate species of bacteria in raw milk collected.

Bacterial isolation and identification: Bacterial isolation and identification was done [9]. Standard procedures were followed to culture, colony identification and so on.

For primary bacteria identification procedure, once pure culture is obtained, [10]. A Gram stain procedure were made to establish the Gram reaction (Gram-positive or Gram-negative), and cellular morphology (Coccus or Rod). Gram-positive cocci bacteria that were identified, further characterized using catalase test, culture on MacConkey agar and growth on Mannitol salt agar. Catalase negative and those grown on MacConkey agar were categorized as Enterococcus species; whereas catalase negative and unable to grow on MacConkey agar was categorized as Streptococcus species. Catalase positive and Gram-positive cocci bacteria which were grown on Mannitol salt agar were categorized as Staphylococcus species. Staphylococcus species with golden-yellow colony, those that ferment mannitol and coagulase positive bacteria were categorized as Staphylococcus aureus [10].

Secondary biochemical tests were done for biochemical characterization. Biochemical tests such as Indole, Methyl-red, Vogesproskauer, Citrate Utilization (IMViC) and Carbohydrate fermentation were carried out [10] and used to characterize enterobacteriacae bacteria.

Data analysis: Data generated entered in Microsoft Excel spread sheet and was summarized by descriptive statistics including mean and standard errors. Association of different factors analyzed using chi- square and $\mathrm{p}$-value; the factor considered to be significant when $\mathrm{p}$ value is less than 0.05

\section{Results and Discussion}

A total of 249 and 200 smallholder dairy farm producers were randomly selected from Hawassa and Debre berhan cities, respectively. The size of herd ranges from 1 up to 13 cows, either local and/or cross breeds having different blood level. Research result indicates that $52 \%$ were local Ethiopian zebu, 42\% Holstein Friesian cross breed, $0.8 \%$ pure Boran, and $2.0 \%$ pure jersey breed having 690 dairy cows observed, of which 490 from Hawassa and 200 from Debre berhan cities, respectively.

\section{Feed source and feeding system}

Feeding system in the study area includes indoor, outdoor and both in a proportion of $46.2 \%, 14.9 \%$ and $37.3 \%$, respectively. However, feed shortage was the major problem in these two cities. Feed source was either from communal grazing or purchase green grass, clover, straw from neighborhood. Supplement feed like wheat bran, barley bran, nugue cake and molasses are scarce but purchased from private enterprise. Dairy farmers they don't have their own established forage field. Shopping grasses as well as concentrate was the main activity for animal owners. The amount of feed given to animals' was not to the level of requirement. Knowledge of feed provision biased towards crossbreeds. Only small holders with cross breed Holstein Friesian cattle provide grass mixed with concentrate than local breed because of their better milk yield. They usually provide better amount of supplement for early lactating cow than late lactating cow, but there was no standard. In general majority (42.9\%) of them uses zero grazing added with few concentrates feed. Followed by communal grazing system with concentrate feed (32.1\%) and finally a proportion of (25.0\%) animal owners feed their animals using only communal grazing system. The types of grass found in both areas were Napier and Rhodes grass which are common types of grass in the area. Legumes, which are important in supplementing protein, do not have routine practice, although their use by smallholder farmers has been reported $[11,12]$. Fodder legume production has challenge such as inaccessibility of land and farmers' were not well aware about quality feed in relation to productivity [12]. Promotion of legume production coupled with proper practical training and diet formulation could be useful to improve dairy cattle production; however, the practice was under grass root level. If there is, the pasture land are often inadequate to provide feed throughout the year; a range of 0.1 to 0.2 ha of land might be the maximum land hold in urban area it may be as wide as 0.5 ha in peri urban area. So the average size of pasture plot is about 0.26 ha. This plot exists only in a few dairy farmers. In Ethiopia in general it is not a requirement to have a plot to conduct dairy farm. As far as there is barn, it is free to start dairy farming. There is no wellorganized mentoring and monitoring system in the sector, which is one of the setbacks for the dairy development in the country. Assuming an average DM yield of $16 \mathrm{t} / \mathrm{ha} /$ year [13], the Napier grass DM yield per year would be $4.2 \mathrm{t} /$ year in 0.26 ha plots. For a lactating cow weighing $500 \mathrm{~kg}$, required daily DM intake would be $15 \mathrm{~kg}$ [13], and this forage would last for about 9 months. If the number of cows is more than one, then the forage ends up within short period of time. In this study majority of them have more than two cows and have no plot for feed production. In addition, the feed supply, frequency and amount given are often inadequate. Reports by Gibbons [14] and Munthali [15] about inadequate feeding of dairy animals by 
Page 3 of 8

smallholder farmers suggest that inadequate feeding coupled with some nutritional deficiencies results in negative energy balance, which in turn contributes to low fertility. Friggens [16] reported that animals with constrained energy reserves either reduce their 'reproductive burden' or delay onset of the next reproductive cycle. For a dairy cow carrying one fetus at a time, reduction of the 'reproductive burden' implies no pregnancy and delayed onset of reproductive cycles means long calving intervals [16]. Hence poor nutrition observed is the major cause of infertility and low productivity of dairy cattle under smallholder systems and recommends more attention has to be given to nutrition.

\section{Housing system}

House constructions in the study area were similar to other part of the country. There was irregularity in type of construction. In urban and peri urban area the roof is made of iron sheet, but the wall varies depending on economic status of the owner, some of them have built with block and the other built with wood and mud, whereas the floor was constructed in concrete, soil compact with or without beddings. Drainage system was not sufficient enough to remove slurry. Most of them dispose the slurry inappropriate place outside their compound; which contaminate nearby water reserve or lake or well. There is no experience of having biogas production system. Almost all have milking pen, only $37 \%$ of them have feeding and water troughs in their compound and the remaining free scavenging, and $40 \%$ respondents have feed store.

The results suggest that some farmers have not fully gripped the importance of proper housing of dairy animals. Inadequate roofing and poor drainage can result in accumulation of slurry during the rainy season, which would be difficult to clean given that the farmers need to perform many tasks, particularly in the rainy season when crop production is a primary issue.

Accumulation of slurry would be detrimental to the animals and provide a medium for pathogens as well as high chances of milk contamination [17]. The use of iron sheet roofs also needs to be critically evaluated because they conduct heat and could be associated with heat stress mainly in the hot-dry season.

\section{Dairy breeds in the study area}

Most of the smallholder dairy farmers in Hawassa and Debrebirhan cities had Holstein Friesian cross breed with local Ethiopian zebu, but there were few pure local breeds too. The study indicated that farmers refused to keep pure exotic breed because of their disease susceptibility and high feed requirement. Pure exotic breed is not common in dairy farm practice, except few large scale dairy farms at government institution and private dairy plants. Local and crossbreeds were dominant as shown in Table 1 . This may be associated with capacity and management skill of farmers. Majorities were cross breed $(37 \%$ and $64 \%$ ) in both cities followed by local zebu, and few jersey and Boran breeds.

\begin{tabular}{|l|l|l|l|l|l|}
\hline Sites & \multicolumn{3}{|l|}{ Breeds } & \\
\hline Hawassa & $\begin{array}{l}\text { Holstein Friesian } \\
\text { Cross breed }\end{array}$ & Local zebu & Jersey & Boran & Total \\
\hline $\mathrm{n}$ & 179 & 291 & 14 & 6 & 490 \\
\hline Proportion & $37 \%$ & $59.4 \%$ & $2.9 \%$ & $1.2 \%$ & 100 \\
\hline
\end{tabular}

\begin{tabular}{|l|l|l|l|l|l|}
\hline \multicolumn{6}{|l|}{ Debrebirhan } \\
\hline $\mathrm{n}$ & 128 & 72 & - & - & - \\
\hline Proportion & $64 \%$ & $36 \%$ & - & - & - \\
\hline
\end{tabular}

Table 1: Types of dairy breeds observed during study period in Hawassa and Debre birhan cities.

\section{Herd structure}

Herd structure shows that there was no bull kept at individual level, especially bull of exotic breed because of management problem no one was interested. This was attributed to management and feed cost. The size of herd structure per respondents' observed as calves, heifers, lactating, pregnant and total herd with an average of 1.8, 0.7, 1.5, 0.6 and 4.6; respectively. The proportion of herd structure indicates that $42.3 \%$ were calves, $14.5 \%$ were heifers, $31.8 \%$ lactating cows and $12.2 \%$ were pregnant. Out of total herd $36.6 \%$ were cross breed dairy cows at Hawassa, whereas in Debrebrihan $64 \%$ were cross breed. This indicates that dairy farm in these two sites were at its grass root level. The situation could be a reflection of country status on dairy farm, where milk production and productivity poorly growing. Heifers and heifer calves are necessary as replacements for cows in the dairy herd, and surplus heifers are an important component of the income from dairy production. Therefore, proper reproductive management is important for successful dairying (Table 2) [18].

\begin{tabular}{|c|c|c|c|c|c|c|}
\hline \multirow{2}{*}{$\begin{array}{l}\text { Sites } \\
\text { Hawassa } \\
\text { city }\end{array}$} & \multicolumn{6}{|c|}{ Herd structure per household } \\
\hline & & $\begin{array}{l}\text { Calve } \\
\text { s }\end{array}$ & Heifers & $\begin{array}{l}\text { Lactatin } \\
\text { g } \\
\text { cows }\end{array}$ & Pregnant & Total herd \\
\hline & $\mathrm{n}$ & 462 & 163 & 356 & 136 & 1119 \\
\hline & range & $0-5$ & $0-3$ & $0-5$ & $0-4$ & $2-13$ \\
\hline & average & 1.8 & 0.7 & 1.5 & 0.6 & 4.6 \\
\hline & $\%$ & 36.5 & 14.5 & 31.8 & 12.2 & 100 \\
\hline \multirow[t]{4}{*}{ Debrebirhan } & $\mathrm{n}$ & 252 & 209 & 239 & 138 & 830 \\
\hline & range & $0-8$ & $0-7$ & $0-9$ & $0-6$ & $2-27$ \\
\hline & average & 1.3 & 1.1 & 1.2 & 0.69 & 4.2 \\
\hline & $\%$ & 30.4 & 25.1 & 28.8 & 16.6 & 100 \\
\hline
\end{tabular}

Table 2: Herd structure in small holder dairy farms in Hawassa and Debre Brehan cities.

Though dairy farm had low milk producing, there was sufficient number of calves and heifers in the herd studied for replacement purpose, considering the herd structure observed. It would be reasonable for farmers to target having at least 25\% heifers for their herds to be maintained. Moran [19] illustrated that a system with $36 \%$ heifers, for example, would have sufficient replacement stock as well as enable sale of breeding stock or allow higher culling rate to improve herd genetics. Most smallholder farmers may not necessarily aim for expanding herds but would benefit from sales of breeding stock. Bebe [20] showed that the proportions of heifers to cows among smallholder farmers in Kenya were related to feeding resources. Farmers that practiced zero grazing keep the proportion of low number of calves 
Page 4 of 8

and heifers through early weaning to sales, and it was concluded that availability of sufficient pastures determined the ability to rear adequate stock replacement heifers.

\section{Breeding}

Cows and heifers were mated using 36\% AI and 63.2\% natural insemination methods in Hawassa, whereas in Debrebirhan breeding conducted using $10 \%$ AI and $90 \%$ natural insemination. Source of semen for AI was from national insemination center at Kaliti, the only semen collection center in the country, which distributes semen throughout the country. Use of natural service varies in these two sites, where at Hawassa 53.4\% open air natural service used mainly for local breeds, whereas at Debrebirhan natural service used for local and cross breeds at proportion of $35.5 \%$ and $55 \%$, respectively. Most of natural services were free of charge $(67.8 \%)$ and the remaining was using hired bull (33.2\%) as shown in Table 3. Natural service preferred more than artificial insemination because of semen availability and /or transportation and other challenges.

There was significant difference between two cities $(\mathrm{p}<0.05)$ in using $\mathrm{AI}$ and natural service, where cross breed animals relatively use more AI (72\%) than natural insemination(29.9\%) in Hawassa; More natural service $(85.3 \%)$ than AI (14.7\%) used for cross breed in Debrebrihan as shown in Table 3. The reason for such difference in Debrebrihan might be there was research center which have bull kept for natural service, which is nearby the city so that community can get access for natural service.

Another reason for AI usage at Hawassa city might be the only option they have is semen, regardless of low conception rate and skill of inseminator. There is no pure or cross breed exotic bull station; the existing bulls are all local zebu, which are not accepted for breeding purpose.

\begin{tabular}{|l|l|l|l|l|}
\hline Site & Breed & Al & Natural & Total \\
\hline \multirow{4}{*}{ Hawassa } & Local zebu & $16(10.8 \%)$ & $132(89.2 \%)$ & 148 \\
\cline { 2 - 5 } & Cross (zebu x HF) & $31(72.1 \%)$ & $12(29.9 \%)$ & 43 \\
\cline { 2 - 5 } & Exotic & $42(77.8 \%)$ & $12(22.2 \%)$ & 54 \\
\cline { 2 - 5 } & Total & $89(36.4 \%)$ & $156(63.6 \%)$ & 247 \\
\hline \multirow{3}{*}{ Debrebirhan } & Local & $1(1.4 \%)$ & $71(98.6 \%)$ & 72 \\
\cline { 2 - 5 } & Cross & $19(14.7 \%)$ & $110(85.3 \%)$ & 129 \\
\cline { 2 - 5 } & Total & $20(10 \%)$ & $181(90 \%)$ & 201 \\
\hline
\end{tabular}

Table 3: Breeding methods using Artificial insemination and natural service at Hawassa and Debre brihan cities.

\section{Community perception on repeat breeders}

Farmers were interviewed about their perception on failure of conception among their dairy cows. Most of natural service users assumed that repeat breeding are due to health problems of the cow (38.9\%) followed by poor knowledge of the attendants (11.6\%) and the remaining group have no idea. Owners who were AI users believe that $52.1 \%$ is due to skill of AI technician followed by poor knowledge of the attendant (35.2\%) and health problem of cow (11.3\%). Well trained and experienced AI technician plays an important role for efficient service conception rate, in addition to semen availability and transport facilities. Knowledge of the attendant recognizing heat period, calling the technician on time is one of the crucial activity as far as attendants' knowledge concerned. Studies in other areas such as Kasungu and Mzimba in Malawi indicated similar problems; AI technicians have challenges such as lack of transport, shortage of AI equipment and high AI technician farmer ratios [21]. These challenges lead to delayed or misused inseminations thereby high calving interval.

\section{Herd health}

Farmers were getting veterinary services from governments, private practitioners, and drug store. Most of smallholders in study area were getting veterinary service through telephone call base. Farmers have reported various health problems in their dairy farm during interview period. Among these reproductive problems the following were reported: retained placenta, uterine prolapse, milk fever, calf mortality, still birth, abortion, infection, dystocia and others. Calf mortality and abortion case receive high proportion among the reported problems followed by infectious diseases like blackleg, foot and mouth, foot abscess as shown in Figure 1. Calves within 1-3 months of age showed relatively high proportion of mortality shown in Figure 2 . The results show that dairy cow health is a challenge among small holder farmers

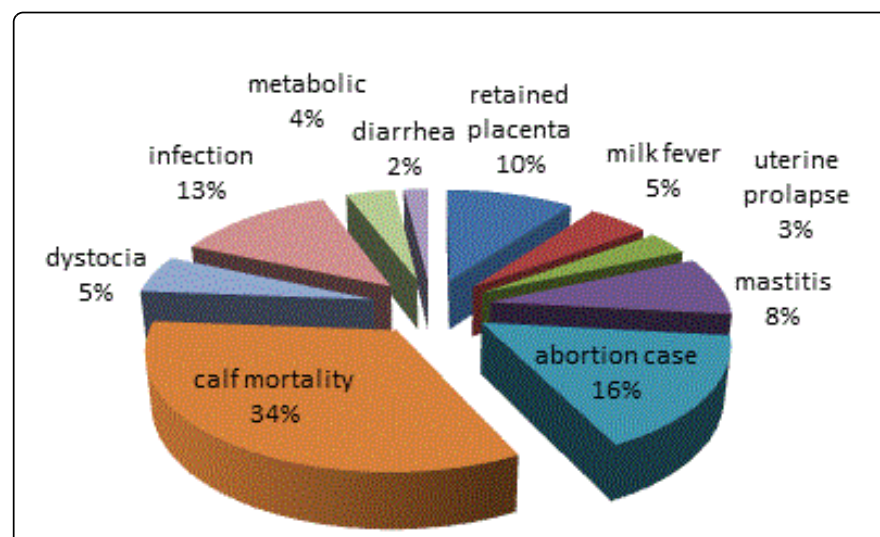

Figure 1: Major Health problems reported in Hawassa and Debre brihan study sites.

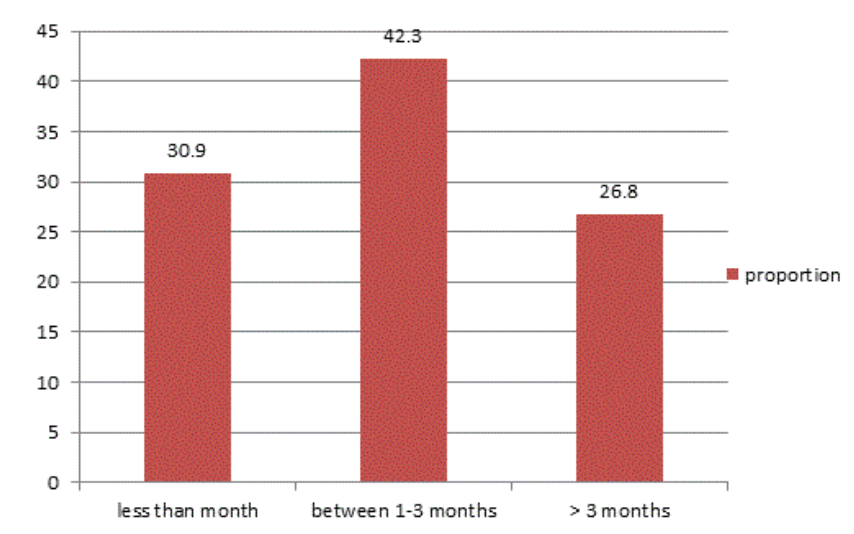

Figure 2: Proportion of calf mortality based on age group. 
Page 5 of 8

However, the report was based on the interview made, which could limit the information depending on the skill of the interviewee and the experience he has; there was also no well documented records to know about reproductive performance in general, health problem in particular in order to quantify and prioritize major problems.

Huttner [22] reported malnutrition and poor animal husbandry as the major predisposing factors to poor animal health among smallholder farms. The combination of health and nutrition challenge in dairy production implies further suppression of animal productivity in terms of milk yield and fertility. It is therefore important to have in place programmes that constantly and systematically monitor and support disease control while providing timely treatments and vaccinations as need arises. This can be achieved through collaboration among stakeholders like farmers, service providers, policy makers and implementers.

\section{Herd productivity}

The main parameter that is used to gauge the efficiency of production in dairy farm is milk. Milk yield varies depending upon the management, stage of lactation and genetic potential of the animals. Milk production in Ethiopian zebu produces an average range of 2-4 liters with minimum of 1 liters and maximum of 6 liters. Cross breed having $75 \%$ blood level and above produces an average range of 6-10 liters with a maximum of 17 liters; whereas jersey, Boran and 50\% cross breed produces an average of 4-6 liters. Level of milk production were dependent on type and amount of feed, when there was concentrate feed in sufficient amount, milk production increases accordingly. However, the link between management and production was not well understood by farmers rather they focus mainly on genetic potential. The yields are generally low when compared with the potential milk yield of the breeds. A wide variation in milk yield is observed among farms, which might be a reflection of differences in management skill.

Farms with access to resources are associated with high yields $[12,17]$. The wide variation between farms indicates that the potential to improve yield by adjusting management in terms of feeding and health exists. Another challenge related to cow productivity is lack of understanding among farmers the relation between management input and productivity.

In addition knowledge about body condition score relationship with productivity and reproductivity is generally overlooked by smallholder dairy farmers. However, BCS is generally recognized to provide a measure of the body energy reserves [23]. Low BCS during late gestation and early lactation is associated with delayed resumption of ovarian cycle which could reduce chances of subsequent reproductive success [24] in terms of parturition and rebreeding interval. BCS is an important trait which forms an integral part of dairy records in many countries and informs cow productivity. However, in this study body condition score was not recorded.

\section{Fertility status}

In this questionnaire survey animal owners were used as primary source of information, there was no record in any farm. All the information was inside the owner mind, one has to ask thoroughly in order to get enough information, however; memory were not equal across the respondents and some of them were not available that made it difficult to get full information. The absence of record in the farm indicates the poor standard of dairy farm. It shows there is no policy or directives which push them to the right truck. The record should be available and used by anyone.

Calving interval was calculated a period between two successive calving. It is probably the best index of a cattle herd's reproductive efficiency. Significant difference $(\mathrm{p}<0.05)$ observed between Arsi zebu and cross breed Holstein Friesian and other breed. Arsi zebu had a mean calving interval of 14.2 months with $\mathrm{SD}+0.44$ months which was greater than other breeds in the study area. Reports by other scholars have shown that Arsi zebu has mean range of 12.9-15.1months and Horro breed had shown 12.2 months [25]. The finding agrees with the previous report. Some suggested that, in N'Dama, Sokoto Gudali and West African Shorthorn cows, calving intervals shorter than 410 days (13.6 months) are very good, those of 411-460 (13.6-15.3 months) are satisfactory and those greater than 461 days (15.3 months) are unsatisfactory. However, season of calving, nutrition, genetic type, age of cow; other factors like sex of calf, health status of cow contribute on calving interval [25]. Relatively longer interval in periurban and large herd size as shown in Debre brihan area might be related to nutrition deficiency and managerial limitation.

\section{Age at first calving}

Under controlled breeding, heifers are usually mated when they are mature enough to withstand the stress of parturition and lactation. This increases the likelihood of early conception after parturition. In traditional production systems, however, breeding is often uncontrolled and heifers are bred at the first opportunity. This frequently results in longer subsequent calving intervals. Researchers have indicated in Ethiopia that of highland zebu had 53 months and east African zebu had 35.1+3.1 months. Arsi zebu had a mean of 33.9 months age at first calving, which was relatively greater than other breed types as shown in Table 4. Local breed in Debrebirhan has shown 45 months. The findings were in agreement with previous work. Heritability's of age at puberty, at first conception and at first calving are generally low, indicating that these traits are highly influenced by environmental factors. Researchers found that Gobra (Senegal Fulani) heifers kept on pasture and fed a balanced concentrate supplement calved first at 31 months old, compared with 40 months for un supplemented heifers [25].

\section{Service per conception}

The number of services per conception (NSC) depends largely on the breeding system used. It is higher under uncontrolled natural breeding and low where hand-mating or artificial insemination is used. NSC values greater than 2.0 should be regarded as poor [25]. In this study natural service conception had 1.18 which was in agreement with previous reports; whereas artificial insemination users (1.5 up to 2.3) as shown in Table 4. This might indicate that there were problems in using AI methods due to various reasons, of these factors feed availability, time of insemination and heat detection plays a major role. Azage et al. [26], using 3 local Ethiopian breeds, the Barca, Horro and Boran, found that NSC was lower for animals from wet areas than for those from drier areas $(1.74 \pm 0.6$ vs $1.98 \pm 0.07)$. Crossbred cows required 0.12 and 0.14 fewer services per conception than local zebu cows in wet and dry areas, respectively. 
Citation: Mekuria S (2016) Smallholder Dairy Farm Management in Ethiopia: Status in Hawassa and Debrebrihan Cities. J Veterinar Sci Technol

Page 6 of 8

\begin{tabular}{|l|l|l|l|l|l|l|l|}
\hline Breed type & $\mathbf{n}$ & $\begin{array}{l}\text { Days open } \\
\text { Mean+SD (days) }\end{array}$ & $\begin{array}{l}\text { Mean } \\
\text { Cl+SD (months) }\end{array}$ & Mean service per conception+SD & $\begin{array}{l}\text { Mean } \\
\text { (months) }\end{array}$ & AFC+ SD & F P-value \\
\hline Arsi zebu & 290 & $161.6 \pm 48.8$ & $14.2 \pm 0.44$ & $1.18 \pm 0.025$ & $33.9 \pm 0.9$ & 3.00 & 0.01 \\
\hline $\begin{array}{l}{ }^{*} \text { Cross breed } \leq 50 \% \\
\text { HF }\end{array}$ & 94 & $133.3 \pm 60.9$ & $12.4 \pm 0.77$ & $1.50 \pm 0.074$ & $27.8 \pm 1.3$ \\
\hline $\begin{array}{l}* * \text { Cross breed } \geq 50 \% \\
\text { HF }\end{array}$ & 86 & $165.0 \pm 76.0$ & $11.3 \pm 0.77$ & $1.72 \pm 0.085$ & $22.9 \pm 1.1$ \\
\hline Boran & 6 & $176.0 \pm 59.0$ & $11.8 \pm 4.00$ & $2.17 \pm 0.31$ & $18.8 \pm 6.1$ \\
\hline Jersey & 14 & $184.0 \pm 25.0$ & $12.4 \pm 1.93$ & $2.29 \pm 0.32$ & $25.4 \pm 3.1$ \\
\hline
\end{tabular}

Table 4: Mean calving interval, service per conception and age at first calving as compared with different breed type in Hawassa and Debrebirhan. ${ }^{\star}$ Cross breed $<50$ percentage Holstein Friesian had similar color like local breed with some morphological difference. ${ }^{*}$ Cross breed $>50 \%$ Holstein Friesian blood level, they have a color of Holstein Friesian.

\section{Bacterial isolate}

In the course of the study, bacteria belongs to the nine genera were isolated. The most predominant were Staphylococcus species $(35.2 \%)$ followed by Streptococcus species (15.7\%), Bacillus species (15.1\%), Enterococcus species (10\%), E. coli (8.2\%), Klebsiella pneumoniae (5\%), Corynebacterium species (4.4\%), Enterobacter aerogenes $(3.8 \%)$ and Citrobacter diversus (2.5\%) as shown in Tables 5-7.

The type and number of bacteria present in milk indicate the hygienic quality of milk. Bacillus species, Staphylococcus species, Micrococcus species, Streptococcus species and coliform microorganisms can cause spoilage of the milk when present in raw and pasteurized milk [27]. In this study $8.8 \%$ of Staphylococcus aureus isolates were identified and this could be a concern of human health as some strains of Staphylococcus aureus are capable of producing heat stable enterotoxin [28]. Though E. coli is a frequent organism in milk and its products [29], however, few verocytotoxigenic strains may cause hemmorhagic colitis; the most important strain is the enterohemmorrhagic type E. coli O157: $\mathrm{H} 7$ [30], that cause food borne illness and is now considered as important human pathogens [31]. Transmission of coliform organisms potentially including E. coli $\mathrm{O} 157$ : $\mathrm{H} 7$ occurs through ingestion of raw milk [32]. In this study $8.2 \%$ of E. coli was isolated and it could be a concern as verocytotoxigenic E. coli strain that can affect consumers' health in milk shed area.

Bacillus cereus produces two different forms of food poisoning; the diarrheal syndrome caused by heat stable enterotoxin and emetic syndrome involving a very heat stable enterotoxin [32]. In this study $15.1 \%$ of Bacillus species were isolated from the milk samples and this need a concern as Bacillus cereus could cause a public health hazard. The bacteria of the genus Enterococcus species also known as Enterococci are considered to be important in food as indicator of spoilage or potential pathogenic organisms. In dairy products both $E$. faecalis and E. faecium species are relatively heat resistant as well. Most enterococci are also relatively resistant to freezing. Higher levels of Enterococci in milk are considered to be the result of contamination during the collection or processing of milk [33]. In this study $10.1 \%$ of Enterococci were isolated which implies a risk that other enteric pathogens may be present in the milk. Enterococci are therefore of particular importance in food and public health microbiology. E. faecalis is as a causative agent of gastro enteritis (Figure 3) [34].

\begin{tabular}{|l|l|l|l|}
\hline Gram stain & Isolates & $\begin{array}{l}\text { No } \\
\text { positive }\end{array}$ & $\begin{array}{l}\text { Relative } \\
\text { percentage }\end{array}$ \\
\hline \multirow{4}{*}{$\begin{array}{l}\text { Gram positive } \\
(128,80.5 \%)\end{array}$} & Bacillus spp. & 24 & 15.1 \\
\cline { 2 - 4 } & Staphylococcus aureus & 14 & 8.8 \\
\cline { 2 - 4 } & $\begin{array}{l}\text { Other Staphylococcus } \\
\text { spp. }\end{array}$ & 42 & 26.4 \\
\cline { 2 - 4 } & Corynebacterium spp. & 7 & 4.4 \\
\cline { 2 - 4 } & Streptococcus spp. & 25 & 15.7 \\
\cline { 2 - 4 } & Enterococcus spp. & 16 & 10.1 \\
\hline \multirow{2}{*}{$\begin{array}{l}\text { Gram negative } \\
(31,19.5 \%)\end{array}$} & E. coli & 13 & 8.2 \\
\cline { 2 - 4 } & Klebsiella pneumonia & 8 & 5 \\
\cline { 2 - 4 } & Citrobacter diversus & 4 & 2.5 \\
\cline { 2 - 4 } & Enterobacter aerogenes & 6 & 3.8 \\
\hline \multirow{2}{*}{ Total } & & 159 & 100 \\
\hline
\end{tabular}

Table 5: Proportion of different bacterial isolates recovered from raw milk of Hawassa city smallholder dairy farms [35].

\begin{tabular}{|l|l|l|l|l|l|l|l|l|}
\hline $\begin{array}{l}\text { Growth on } \\
\text { blood agar }\end{array}$ & $\begin{array}{l}\text { growth } \\
\text { MacConkey }\end{array}$ & $\begin{array}{l}\text { Gram } \\
\text { Stain }\end{array}$ & $\begin{array}{l}\text { Arrangement on } \\
\text { staining }\end{array}$ & Catalase & $\begin{array}{l}\text { Mannitol salt } \\
\text { agar }\end{array}$ & $\begin{array}{l}\text { Lactose } \\
\text { fermentation on } \\
\text { MacConkey }\end{array}$ & Coagulase & Bactria isolated \\
\hline+ & - & + rod & large rod & + & - & - & - & Bacillus spp. \\
\hline+ & - & + cocci & Cluster & + & - & - & - & Staphylococcus spp. \\
\hline+ & - & + cocci & Cluster & + & golden yellow & - & + & Staphylococcus aureus \\
\hline
\end{tabular}


Citation: Mekuria S (2016) Smallholder Dairy Farm Management in Ethiopia: Status in Hawassa and Debrebrihan Cities. J Veterinar Sci Technol

Page 7 of 8

\begin{tabular}{|l|l|l|l|l|l|l|l|l|}
\hline+ & - & $+\operatorname{rod}$ & Irregular & + & - & - & - & Corynebacterium spp. \\
\hline+ & - & + cocci & Chain & - & - & - & - & Streptococcus spp. \\
\hline+ & Pink & + cocci & Chain & - & - & + & - & Enterococcus spp. \\
\hline
\end{tabular}

Table 6: Isolation and characterization of Gram positive bacteria [35].

\begin{tabular}{|c|c|c|c|c|c|c|c|c|c|c|c|c|}
\hline $\begin{array}{l}\text { Growth } \\
\text { MacConkey }\end{array}$ & $\begin{array}{l}\text { Gram stain } \\
\text { /KoH }\end{array}$ & Catalase & $\begin{array}{l}\text { lactose on } \\
\text { MacConkey }\end{array}$ & Indole & Methyl red & $\begin{array}{l}\text { Voges- } \\
\text { Proskuer }\end{array}$ & citrate & urease & TSI slant/but & $\mathrm{H} 2 \mathrm{~S}$ & Motility & $\begin{array}{l}\text { Bacteria } \\
\text { isolated }\end{array}$ \\
\hline Pink & Rod & + & - & - & - & + & + & + & $y / y$ & - & + & $\begin{array}{l}\text { Enterobacter } \\
\text { spp. }\end{array}$ \\
\hline Pink & - rod & - & + & - & - & + & + & + & $y / y$ & - & - & Klebsiella \\
\hline Pink & rod & + & + & + & + & - & - & - & $y / y$ & - & + & E. coli \\
\hline Pale & rod & + & - & + & + & - & + & + & $R / Y$ & - & + & Citrobacter spp. \\
\hline
\end{tabular}

Table 7: Gram negative isolates and their biochemical characteristics [35].
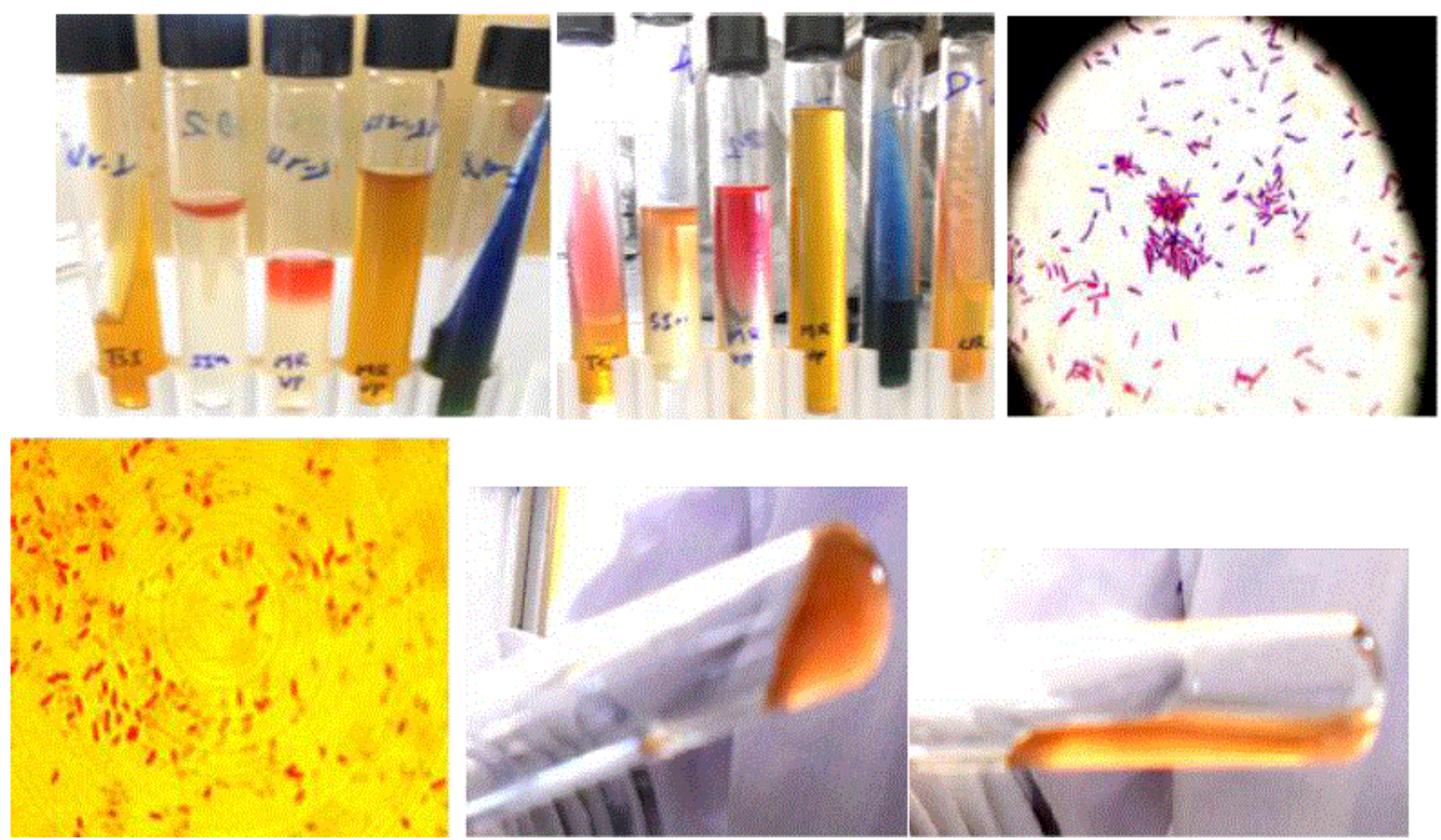

Figure 3: Biochemical test, gram stain and coagulase test results from left to right (IMViC test, gram positive and negative then coagulase positive and negative results) shown during milk bacteriology study.

\section{Conclusion and Recommendation}

Smallholder dairy farms in Ethiopia particularly in regional and zonal cities are alarmingly increasing because of high demand of milk and milk product from resident. However, the existing farming system which holds maximum of 10 or 15 cows per individual is not satisfactory to fulfill the demand. Furthermore, farming system has a major problem with regards to feed source, feed supply and the amount given per animal was below the minimum standard, which entails in reduction in production and reproduction in the farm. In addition, snapshot observation on milk bacteriology has shown that milk hygiene was poor and can result intoxication because of few pathogenic spp. 
Therefore based on the above conclusion the following recommendations are forwarded:

There must be strict policy that can ensure a minimum requirement for the dairy farm to be established. Otherwise, everybody who has many and shelter, but no grazing land will continue to establish, which affect the environment as well as results in poor productivity.

Awareness of animal owner and stakeholder should be raised in order to increase their management ability. As management significantly affect productivity and reproductive in dairy farm.

Minimum standard should be set during milking and collection center in order to minimize bacterial contamination.

\section{References}

1. MOA (Ministry of agriculture) (2000) Second five year national Livestock development plan of federal democratic republic Ethiopia. MOA, Addis Ababa, Ethiopia.

2. Heinrichs AJ (1993) Raising dairy replacements to meet the needs of the 21st century. J Dairy Sci 76: 3179-3187.

3. Winter LM (2002) Animal breeding. Green world public sheers Andria Nagar, India.

4. Mukasa M, Azage E, Tafesse M, Teklu Y (1991) Reproductive efficiency of Bos idicus (zebu) cows under Artificial insemination. Anim. reprod sci 24: 63-72.

5. Mekonnen D (2000) Study on major infertility problem of cross Breed dairy herd in Adaa district of central Ethiopia, DVM Thesis, Faculty of Veterinary Medicine, Addis Ababa University, Ethiopia.

6. Hooijer GA, Frankena K, Valks MM, Schuring M (1999) Treatment of cystic ovarian disease in dairy cows with gonadotrophin-releasing hormone: a field study. Vet Q 21: 33-37.

7. Hubble (2007) Heat detection, dairy research, development and Extension.

8. CSA (central statistical authority) (2009) Ethiopia statistical abstracts. Central statistical authority, Addis Ababa, Ethiopia.

9. Quinn PJ, Carter ME, Markey A, Carter GR, ( 2002) Clinical Veterinary Microbiology. London. Mosby publishing pp: 43-55.

10. Bramely AJ, Mckinnon CH (1990) The microbiology of raw milk. In: Dairy Microbiology 1: 163-208.

11. Chakeredza S, Akinnifesi FK, Ajayi OC, Sileshi G, Mngomba S, et al. (2008) A simple method of formulating least-cost diets for smallholder dairy production in sub-Saharan Africa. African Journal of Biotechnology 7: 2925-2933.

12. Chindime SCC (2008) The role of in-kind credit on milk productivity among credit participating and non-participating dairy farmers: A case study of Central and Northern Milk shed Areas. Rufourm.

13. Orodho $\mathrm{AB}$ (2006) The role and importance of Napier grass in the smallholder dairy industry in Kenya. Food and Agriculture Organization, Rome.

14. Gibbons JM, Kawonga B, Gondwe TN, Chagunda MG, Roberts DJ (2010) Measuring welfare of dairy cattle in Malawi: Challenges, constraints and opportunities. In: Haile A and Tadesse F (Eds), Proceedings of the 5th all Africa conference on animal agriculture, Addis Ababa, Ethiopia.

15. Munthali JTK, Musa FA, Chiwayula CLK (1992) Smallholder dairy development in Malawi. In: Kategile JA, Mubi S (Eds) Proceedings of a workshop on future of livestock industries in East and Southern Africa, Kadoma.

16. Friggens NC (2003) Body lipid reserves and the reproductive cycle: towards a better understanding, Livestock Production Science, 83: 219236.
17. Banda LJ, Kamwanja LA, Chagunda MG, Ashworth CJ, Roberts DJ (2012) Status of dairy cow management and fertility in smallholder farms in Malawi. Trop Anim Health Prod 44: 715-727.

18. Stewart PG (2005) Dairy herd structure/Dairy herd dynamics, Cedara Agricultural Development Institute, Department of Agriculture, Environmental Affairs and Rural Development, Kwazulu Natal Province.

19. Moran JB (2009) Key performance indicators to diagnose poor farm performance and profitability of smallholder dairy farmers in Asia, The Free Library.

20. Bebe BO (2008b) Dairy heifer rearing under increasing intensification of smallholder dairy systems in the Kenya highlands. Livestock Research for Rural Development 20: 22.

21. Masangano C, Wellard K, Banda L, Fatch P, Gausi W, et al. (2009) Increasing agricultural productivity and food security through capacity building of extension workers and veterinarians in Malawi.

22. Huttner K (2000) Impact Assessment of a Community-based Animal Health Service Program in northern Malawi.

23. Roche JR, Friggens NC, Kay JK, Fisher MW, Stafford KJ, et al. (2009) Invited review: Body condition score and its association with dairy cow productivity, health, and welfare. J Dairy Sci 92: 5769-5801.

24. Chagas LM, Bass JJ, Blache D, Burke CR, Kay JK, et al. (2007) New perspectives on the roles of nutrition and metabolic priorities in the sub fertility of high-producing dairy cows, Journal of Dairy Science 90: 40224032.

25. FAO (2015) Measures of reproductive performance.

26. Azage T, Galal ESE, Beyene K (1981) A study on the reproduction of local zebu and F1 crossbred (European x zebu) cows. Number of services per conception, gestation length and days open till conception. Ethiopian Journal of Agricultural Sciences 3: 1-14.

27. Doyle MP, Beuchat LR, Montville TJ (1997) Food Microbiology. Fundamentals and Frontiers. ASM, Washington DC pp: 100-115.

28. Chambers JV (2002) The microbiology of raw milk. In: Dairy Microbiology Handbook, (3rd Edn) John Wiley and Sons, New York, pp: 39-90.

29. Hahn G (1996) Pathogenic bacteria in raw milk-situation and significance. Symposium on Bacteriological Quality of Raw milk, Wolf passing, Austria.

30. Leclerc VB, Dufour B, Lomberd F, Gauchard B, Garin-Bastuji G, et al. (2002) Pathogens in meat and milk products: Surveillance and impact on human health in France. Livestock Production Science 76: 195-202.

31. Pennington H (1997) Report on the Circumstance leading to the 1996 outbreak of infection with E. coli O157 in Central Scotland, the implication for food safety and lessons to be learned, the stationary office, Edinburgh.

32. Kivaria FM, Noordhuizen JP, Kapaga AM (2006) Evaluation of the hygienic quality and associated public health hazards of raw milk marketed by smallholder dairy producers in the Dar es Salaam region, Tanzania. Trop Anim Health Prod 38: 185-194.

33. Cogan TM, Barbosa M, Beuver E, Bisnvhi-Dslbsfoti E, Cocconcelli PS, et al. (1997) Characterization of the lactic acid bacteria in artisanal dairy products. Journal of Dairy Research 64: 409-421.

34. Cousins CM, Bramley JA (1985) The microbiology of raw milk. Dairy Microbilogy 1: 119-163.

35. Mekuria S, Regassa A, Abebe R, Fekade A, Dires B (2014) Bacteriological study on raw milk collected from Hawassa smallholder dairy farms. Advances in biological research 8: 194-200. 